International Journal of Agriculture, Environment and Bioresearch

Vol. 4, No. 06; 2019

ISSN: $2456-8643$

\title{
PRESENCE AND PREVALENCE OF BRACHYSPIRA PILOSICOLI COLONISATION IN DOGS IN ISTANBUL, TURKEY
}

\author{
Baran CELIK ${ }^{1 *}$ and Seyyal AK ${ }^{2}$ \\ ${ }^{1}$ Department of Microbiology, Faculty of Veterinary Medicine, Istanbul University-Cerrahpaşa, Istanbul 34320- \\ TURKEY \\ ${ }^{2}$ Department of Microbiology, Faculty of Veterinary Medicine, Istanbul University-Cerrahpaşa, Istanbul 34320- \\ TURKEY
}

http://doi.org/10.35410/IJAEB.2019.4489

\begin{abstract}
In this study, it was aimed to determine the presence of Brachyspira pilosicoli colonization in dogs, to determine its prevalence and to investigate the relationship between colonization and various physiological, pathological and behavioural variables such as diarrhoea, age, sex and contact with other animals. For this purpose, faecal specimens were collected from 192 dogs (96 with diarrhoea and 96 healthy controls). Faecal samples were specifically cultured for Brachyspira species. 10 presumptive Bra-chyspira spp. isolated, biochemical and enzymatic properties of the isolates were evaluated and identified using PCR. The prevalence of B.pilosicoli was found as $4.68 \%(\mathrm{n}=9)$. The relationship between diarrhoea and B.pilosicoli colonization in dogs has been shown to be statistically significant ( $\mathrm{P}<0.001)$. The presence of contact with other dogs and B.pilosicoli colonization were statistically significant $(\mathrm{P}=0.033)$. There was no statistical relationship between age and sex with colonization.
\end{abstract}

Keywords: Dog, B. pilosicoli, prevalence, culture, PCR.

\section{INTRODUCTION}

B.pilosicoli is a causative agent of colonic or intestinal spirochetosis, characterized by attachment to the cecal and colon mucosa and epithelial damage in animals and humans (BaitMerabet et al.,2008). The presence of B.pilosicoli in the intestines has been demonstrated in numerous host such as human, pig, dog, opossum, wild and domestic fowls (Takeuchi et al.,1974, Duhamel et al.,1995, Swayne and McLaren,1997) and its inter-species transmission and zoonotic potential has been demonstrated in various studies (Trott et al.,1996, Trott et al.,1997, Trott and Hampson,1998). B.pilosicoli is associated with gastrointestinal diseases in humans such as chronic diarrhoea, abdominal pain and bleeding. Colitis and hepatitis may be observed in more severe cases and septicaemia may be observed in immune compromised individuals (Mikosza et al.,2001, Bait-Merabet et al.,2008).

In dogs, the disease is symptomatic mostly animals under one year of age with chronic diarrhoea and wasting. No symptom is observed in adults; they are subclinical carriers that transmit the agent to susceptible animals (Duhamel et al.,1995, Duhamel,2001). Spirochaetal 
attachment in intestinal specimens of dogs has been known for centuries. But, pathogenesis of B.pilosicoli is controversial since the agent can be found both healthy and symptomatic animals' faecal and colon biopsy specimens. However, due to the development of molecular techniques, it has been shown that the spirochetes found in healthy animals are B.murdochii or B.innocens (Stanton et al.,1997) and the agent detected in symptomatic animals is B.pilosicoli (Duhamel et al.,1995, Duhamel et al.,1998).

Objectives of this study are to investigate the existence, prevalence and colonization of B.pilosicoli in dogs and its possible relationship with various physiological and behavioural variables.

\section{MATERIALS AND METHODS}

Study approved by the Ethical Committee of Istanbul University, Faculty of Veterinary Medicine. Approval no: 2010/155.

Faecal samples were collected from an equal number (96, predicted prevalence $\% 50$, with an absolute error of $10 \%$ and a $95 \%$ confidence level) of healthy and symptomatic dogs from veterinary clinics, breeders, pet-shops, and the department of internal medicine clinic at Faculty of Veterinary Medicine. Samples were collected directly from the rectum of the animals with sterile bacteriological swabs. The collected samples were recorded, and the questionnaire was filled in for information (status of faeces, age, gender, contact with other dogs, breed, any current drug treatment) about the sampled dog. Samples were inoculated onto the selective medium previously described by Fellstrom et al. (1999) and Rasback et al. (2006). The plates were incubated for 5 to 7 days at $42{ }^{\circ} \mathrm{C}$ in a jar with an anaerobic environment generated using a GasPak disposable hydrogen plus carbon dioxide generator envelope with a palladium catalyst (Oxoid, AN0035). Slides were prepared from plates with weak-haemolytic colonies and examined microscopically by Gram staining. In order to maximize growth, cultures with weak haemolysis, film-like or s type grey colonies were subcultured onto Fastidious Anaerobe agar (FAA) (Fellstrom et al.,1997, Fellstrom et al.,2001). Phenotypic characterization was performed by previously described (Fellstrom and Gunnarsson,1995). Enzymatic reactions determined by APIZYM system (APIZYM, 2500, bioMérieux) as described by the manufacturer. B. pilosicoli P43/6/78T (ATCC 51139) was used as positive control.

The isolates were analysed by PCR using species-specific primers to confirm identification as described before (Fellstrom et al.,1997, Fellstrom et al.,2001). Chromosomal DNA extraction was performed by boiling. The isolates were taken from the solid culture and boiled in $50 \mu 1$ of purified water for 10 minutes. The supernatant was used as the template DNA in the PCR analyses.

All calculations and statistical analyses were performed with the Statistical Package for Social Sciences -SPSS for Windows, release 17.0 (IBM, SPSS Inc., Chicago, IL). The associations between presence and absence of B.pilosicoli and each of the categorical variables was investigated using the Pearson chi-square test of independence and Fisher's Exact test (expected cell value null or <5). The categorical variables used include age (1 year and less, bigger than 1 year old), gender (male, female), contact with other dogs (yes, unknown, or no), having diarrhoea (yes or no). 


\section{RESULTS}

Brachyspira spp. suspected colonies were isolated from 8 of the 96 faecal samples of the dogs with diarrhoea. These suspected isolates were identified as B. pilosicoli by conventional biochemical tests Brachyspira spp. suspected colonies were isolated from 8 of the 96 faecal samples of the dogs with diarrhoea. These suspected isolates were identified as $B$. pilosicoli by conventional biochemical tests.

Brachyspira spp. suspected colonies were isolated from 2 of the 96 faecal samples of the dogs without diarrhoea (samples 43 and 126). According to biochemical tests performed, these isolates were considered as B. pilosicoli.

All isolates were examined for the presence of specific B. pilosicoli DNA, by species-specific PCR. All 1 of the isolates from diarrheic dogs and only one of the isolate from healthy ones were defined as $B$. pilosicoli (picture 1 and 2, table 1). In this study, the prevalence of the B. pilosicoli in Istanbul was found; $4.68 \%$ in all samples; $8.3 \%(n=8)$; in dogs with diarrhoea; $1.04 \%$ in dogs without diarrhoea $(n=1)$. The presence of colonization in dogs with diarrhoea was found statistically significant $(\mathrm{p}=0.01)$. Dogs which were in contact with other dogs and colonization were found to be statistically significant $(\mathrm{p}=0.033)$, but relationships between age $(\mathrm{p}=0.655)$, gender $(\mathrm{p}=0.121)$ and colonization were found to be statistically insignificant.

Table 1 Biochemical and enzymatic properties of the isolates

\begin{tabular}{|c|c|c|c|c|c|c|c|c|c|c|c|c|c|c|c|c|c|c|c|c|c|c|c|}
\hline 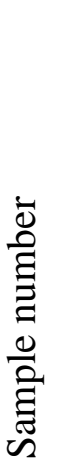 & 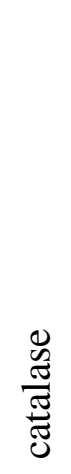 & 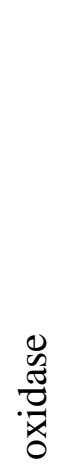 & $\begin{array}{l}\frac{0}{0} \\
\frac{0}{0}\end{array}$ & 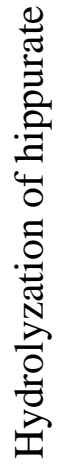 & 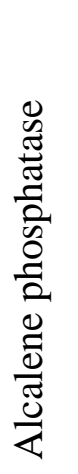 & 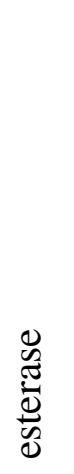 & 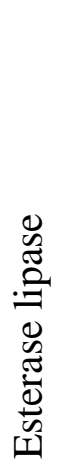 & $\begin{array}{l}\mathscr{\Xi} \\
\tilde{\Xi} \\
: \\
:\end{array}$ & 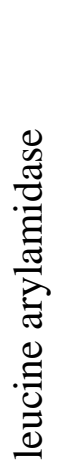 & 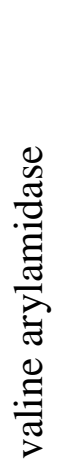 & 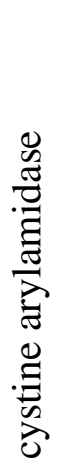 & 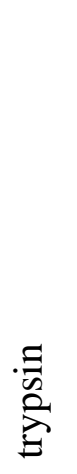 & 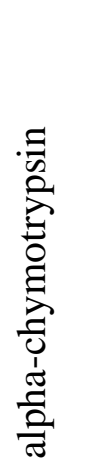 & 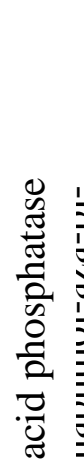 & 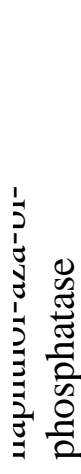 & 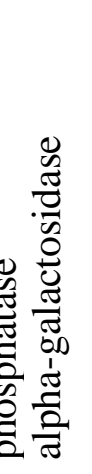 & 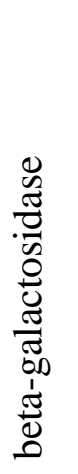 & 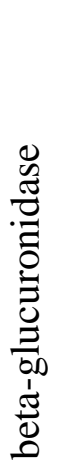 & 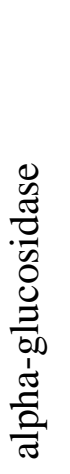 & 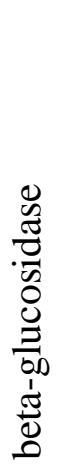 & 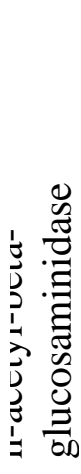 & 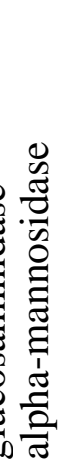 & 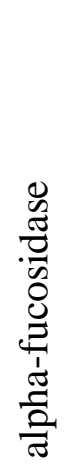 \\
\hline 43 & - & + & - & + & 2 & 4 & 5 & 0 & 0 & 0 & 0 & 0 & 3 & 1 & 0 & 3 & 0 & 0 & 1 & 4 & 0 & 0 & 0 \\
\hline $\begin{array}{l}11 \\
8\end{array}$ & - & + & - & + & 1 & 2 & 1 & 0 & 0 & 0 & 0 & 0 & 0 & 2 & 1 & 5 & 5 & 0 & 0 & 0 & 0 & 0 & 0 \\
\hline $\begin{array}{l}11 \\
9\end{array}$ & - & + & - & + & 2 & 3 & 2 & 0 & 0 & 0 & 0 & 0 & 0 & 2 & 1 & 5 & 5 & 0 & 0 & 0 & 0 & 0 & 0 \\
\hline $\begin{array}{l}12 \\
3\end{array}$ & - & + & - & + & 2 & 4 & 5 & 0 & 0 & 0 & 1 & 0 & 0 & 1 & 0 & 5 & 5 & 0 & 0 & 0 & 0 & 0 & 0 \\
\hline 12 & - & + & - & + & 3 & 3 & 4 & 0 & 1 & 0 & 0 & 0 & 0 & 4 & 2 & 5 & 5 & 0 & 0 & 0 & 0 & 0 & 0 \\
\hline
\end{tabular}




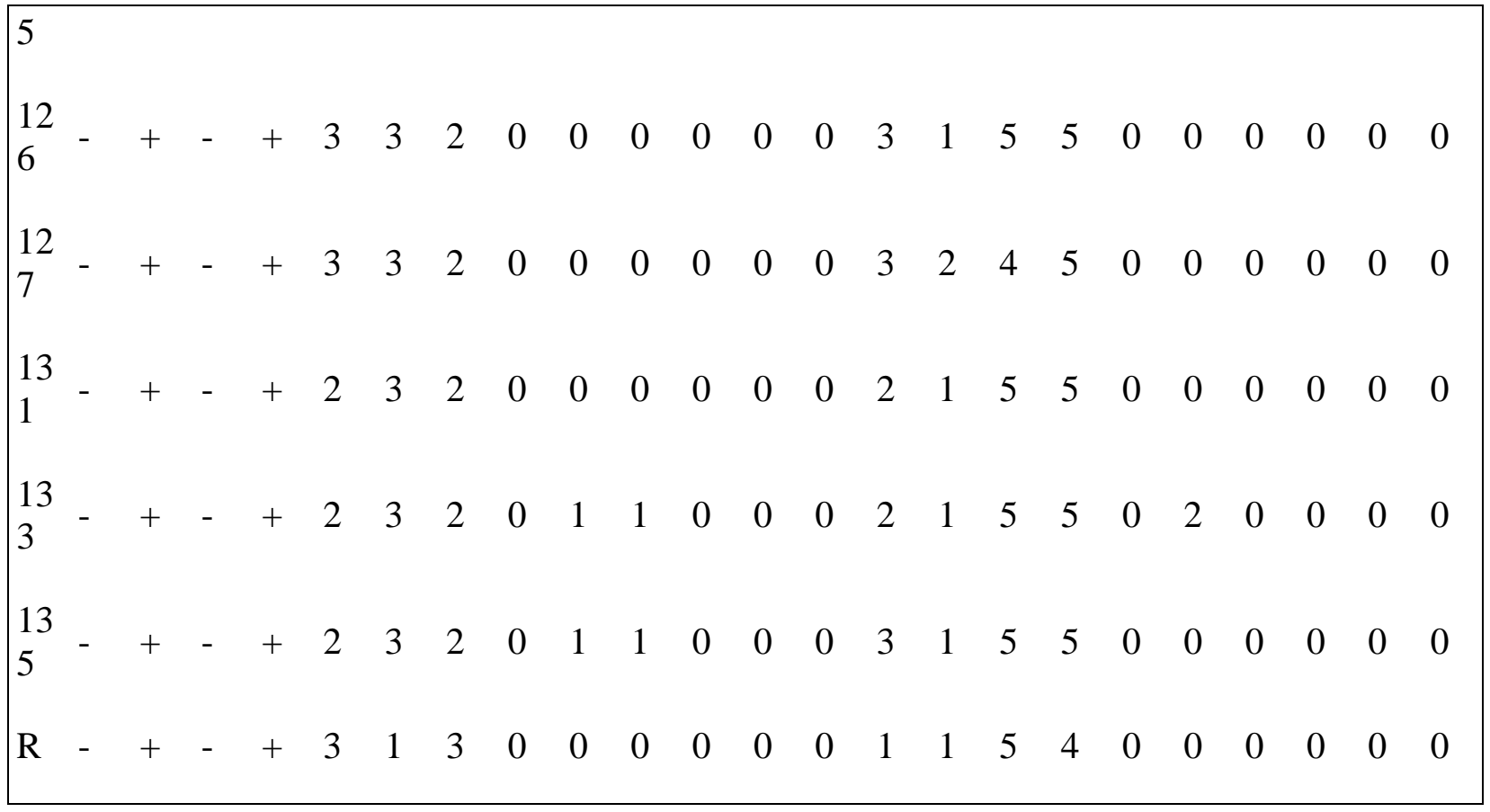

R: reference, -: negative, + positive, 0 to 5 (weaker to strong) is color intensity of the reactions in APIZYM test

Picture 1 Gram staining of the sample 123

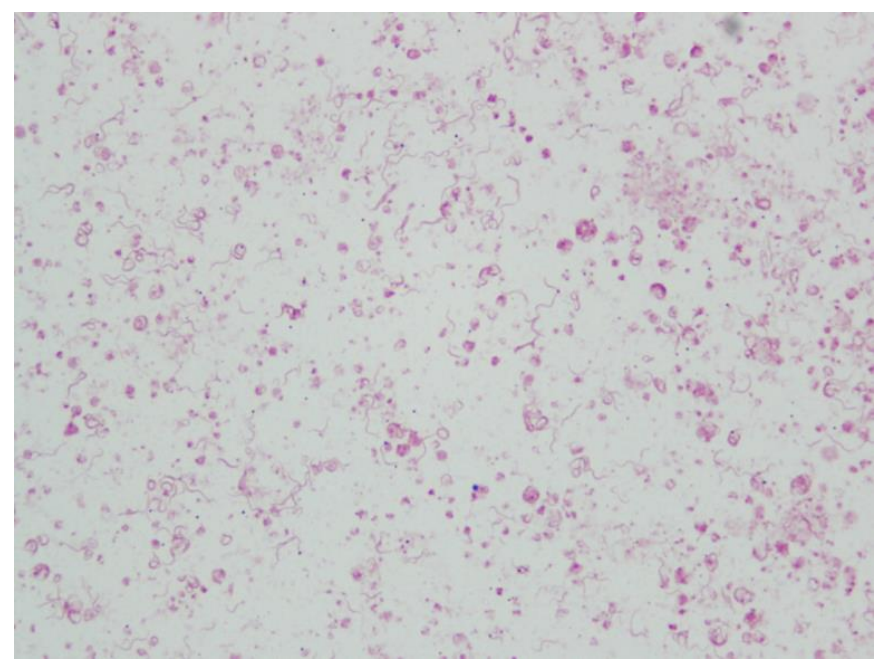

Picture 2 Trans-illumination picture of the samples' PCR analysis 


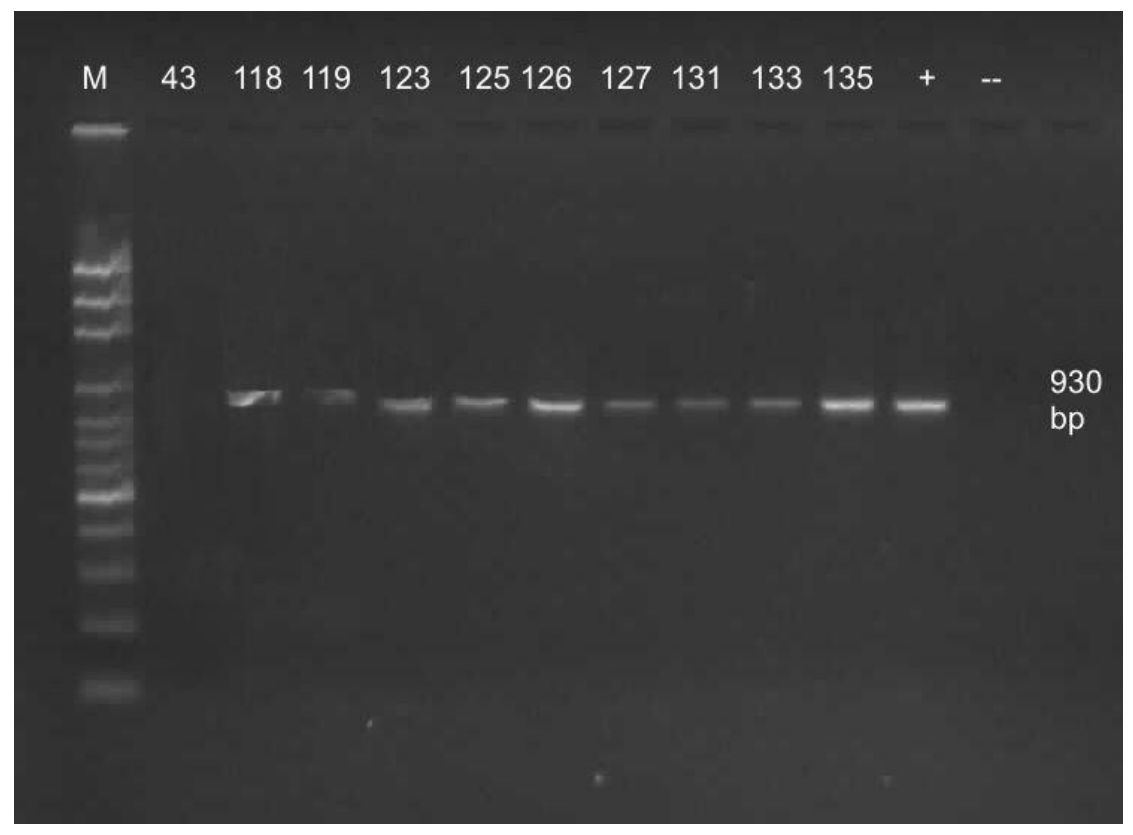

\section{DISCUSSION}

B. pilosicoli which was increasingly gained importance and has been associated with various diseases was detected in the numerous hosts, including humans and particularly dogs, pigs and chickens (Duhamel et al.,1997, Muniappa et al.,1997, Swayne and McLaren,1997). Most of the studies are concentrated on especially isolation and infections caused by in people because this bacterium is a newly recognized agent. B. pilosicoli isolation and associated diseases of humans, pigs, chickens and dogs have been reported in many countries (Duhamel et al.,1995, Duhamel et al.,1995, Mikosza et al.,1999).

The prevalence of the B. pilosicoli in dogs reported in several studies, 5.3\% in Papua New Guinea; 9.37\% in Sweden; 0.9\% in India's Assam state; in Western Australia 14.2\%; in Spain and $4.8 \%$ (Fellstrom et al.,1997, Trott et al.,1997, Oxberry and Hampson,2003, Munshi et al.,2004, Hidalgo et al.,2010).

In this study, the prevalence of the B. pilosicoli in Istanbul was found; $4.68 \%$ in all samples; $8.3 \%(\mathrm{n}=8)$; in dogs with diarrhoea; $1.04 \%$ in dogs without diarrhoea $(\mathrm{n}=1)$. Prevalence has been increased, when diarrhoea taking into account compared with other studies.

In this study, the presence of colonization in dogs with diarrhoea was found statistically significant $(\mathrm{p}=0.05)$. Oxberry and Hampson (2003) reported that colonization was not associated with diarrhoea. However, Hidalgo et al. (2010), have demonstrated the relationship between the $B$. pilosicoli colonization in the dogs and diarrhoea statistically significant. The results of this study are consistent with the results of Hidalgo et al. (2010). 
In this study, contact with other dogs was found to be statistically significant ( $\mathrm{p}=0.033)$, but gender and age were found to be statistically insignificant in terms of colonization. Margawani et al. (2004) in Bali, Indonesia have reported that no statistically significant relationship between age, animal contact and gender with colonization. It is thought that the difference observed with the results of previous studies on this subject is due to the distribution and number of samples.

Qualification of culture and phenotypic tests adequacy for Brachyspira species identification was a matter of debate and necessity of addition to molecular methods for this purpose have been discussed for years (Fellstrom et al.,1997, Stanton et al.,1997, Hommez et al.,1998, Fossi et al.,2004, Fossi and Skrzypczak,2006). Fellstrom et al. (1997) was emphasized that indole production and hippurate hydrolysis tests as the most important tests in the identification of Brachyspira species. $\alpha$-galactosidase and $\beta$-glucosidase tests have been proposed as supplementary tests for identification. Hommez et al. (1998) reported that there may be some variant bacteria within Brachyspira species, and identification based on phenotypic tests might produce incorrect results. In the study of Fellstrom et al. (2001), the isolate A3077 was classified as B. pilosicoli as a result of PFGE and 16S rRNA gene sequencing tests, but this isolate was strongly positive about indole reaction. This atypical isolate, reported as first indole positive WBHIS strain which was isolated from dogs besides B.intermedia isolates. Fossi et al. (2004) showed that hippurate negative, B.pilosicoli-like isolates were identified as B.pilosicoli. They also emphasize that, if Fellstrom et al. (1997)'s phenotypical identification diagram fallowed, this hippurate-negative atypical B.pilosicoli strains was mixed up with B.murdochii, and using of specific PCR assays for accurate identification was necessary. However, they report that hippurate and $\beta$-glucosidase negative isolates was identified as B.pilosicoli in laboratories with inadequate for molecular techniques. Also, there was some studies that culture was more sensitive than PCR that considering about detection limit of the bacteria (Fellstrom et al.,1997, Stege et al.,2000, Fellstrom et al.,2001). On the other hand, it was reported that, in some cases faecal specimens was transported in optimum conditions such as into accurate transport media, anaerobe transport systems, in very short time, this delicate bacteria might not be survive and could not be cultured (Rasback et al.,2006). It was also known that bacteria might be lost of vitality from the samples taken from the individuals who under the antimicrobial treatment (Nathues et al.,2007). For these reasons, the isolation and identification of B.pilosicoli; culture, biochemical tests and molecular techniques has to be evaluated overall.

In this study, an isolate (sample number: 43) was interpreted as presumptive B.pilosicoli due to phenotypical and biochemical properties. Results of the tests showed that isolate has not matched the Fellström, Petterson et al. (1997)'s any of the main phenotypical groups. This isolate has positive $\beta$-glucosidase and negative $\alpha$-galactosidase activities such as B.alvinipulli. But, Duhamel et al. (1998) reported that a B.pilosicoli isolate (Dog17) has positive $\beta$-glucosidase activity, for this reason this dubious isolate was included in the molecular assessment, and found to be negative by species-specific PCR. Therefore even though phenotypic assessment table is a useful diagnostic tool for the identification of B.pilosicoli, the results showed phenotypic assessment has to be supported by molecular methods, as suggested by other researchers (Fellstrom et al.,1997, Fossi et al.,2004, Fossi and Skrzypczak, 2006). 
In this study B.piosicoli presence in dog population in Istanbul has been demonstrated. Colonization in dogs with diarrhoea was found to be statistically significant and contact with the other dogs was found to be a risk factor for colonization. B.pilosicoli is an anaerobic enteric pathogen which is capable of colonization a very broad host range that appears likely to cause zoonotic infections. There are many unknown aspects about it. Therefore, it has been concluded to necessary to sustain related studies.

\section{ACKNOWLEDGEMENTS}

This work was supported by Scientific Research Projects Coordination Unit of Istanbul University. Project number: 12329.

This publication is part of the doctoral dissertation of the first author.

\section{REFERENCES}

Bait-Merabet L, Thille A, Legrand P, Brun-Buisson C, Cattoir V (2008). Brachyspira pilosicoli bloodstream infections: case report and review of the literature. Ann Clin Microbiol Antimicrob. 7(1):19.

Duhamel G, Muniappa N, Mathiesen M, Gardner I, Anderson M, Blanchard P, et al. (1995). Porcine colonic spirochaetosis: a diarrhoeal disease associated with a newly recognised species of intestinal spirochaetes. Pig Journal.

Duhamel G, Trott D, Muniappa N, Mathiesen M, Tarasiuk K, Lee J, et al. (1998). Canine Intestinal Spirochetes Consist ofSerpulina pilosicoli and a Newly Identified Group Provisionally Designated "Serpulina canis" sp. nov. Journal of clinical microbiology. 36(8):2264-2270.

Duhamel GE (2001). Comparative pathology and pathogenesis of naturally acquired and experimentally induced colonic spirochetosis. Anim Health Res Rev. 2(1):3-17.

Duhamel GE, Elder RO, Muniappa N, Mathiesen MR, Wong VJ, Tarara RP (1997). Colonic spirochetal infections in nonhuman primates that were associated with Brachyspira aalborgi, Serpulina pilosicoli, and unclassified flagellated bacteria. Clinical Infectious Diseases. 25:S186S188.

Duhamel GE, Muniappa N, Mathiesen MR, Johnson JL, Toth J, Elder RO, et al. (1995). Certain canine weakly beta-hemolytic intestinal spirochetes are phenotypically and genotypically related to spirochetes associated with human and porcine intestinal spirochetosis. J Clin Microbiol. 33(8):2212-2215.

Fellstrom C, Gunnarsson A (1995). Phenotypical characterisation of intestinal spirochaetes isolated from pigs. Res Vet Sci. 59(1):1-4.

Fellstrom C, Karlsson M, Pettersson B, Zimmerman U, Gunnarsson A, Aspan A (1999). Emended descriptions of indole negative and indole positive isolates of Brachyspira (Serpulina) hyodysenteriae. Vet Microbiol. 70(3-4):225-238.

Fellstrom C, Pettersson B, Thomson J, Gunnarsson A, Persson M, Johansson KE (1997). Identification of Serpulina species associated with porcine colitis by biochemical analysis and PCR. J Clin Microbiol. 35(2):462-467.

Fellstrom C, Pettersson B, Zimmerman U, Gunnarsson A, Feinstein R (2001). Classification of Brachyspira spp. isolated from Swedish dogs. Anim Health Res Rev. 2(1):75-82. 
Vol. 4, No. 06; 2019

ISSN: $2456-8643$

Fossi M, Pohjanvirta T, Sukura A, Heinikainen S, Lindecrona R, Pelkonen S (2004). Molecular and ultrastructural characterization of porcine hippurate-negative Brachyspira pilosicoli. J Clin Microbiol. 42(7):3153-3158.

Fossi M, Skrzypczak T (2006). D-ribose utilisation differentiates porcine Brachyspira pilosicoli from other porcine Brachyspira species. Anaerobe. 12(2):110-113.

Hidalgo A, Rubio P, Osorio J, Carvajal A (2010). Prevalence of Brachyspira pilosicoli and "Brachyspira canis" in dogs and their association with diarrhoea. Veterinary Microbiology. 146(3-4):356-360.

Hommez J, Castryck F, Haesebrouck F, Devriese LA (1998). Identification of porcine Serpulina strains in routine diagnostic bacteriology. Vet Microbiol. 62(2):163-169.

Margawani KR, Robertson ID, Brooke CJ, Hampson DJ (2004). Prevalence, risk factors and molecular epidemiology of Brachyspira pilosicoli in humans on the island of Bali, Indonesia. $\mathbf{J}$ Med Microbiol. 53(Pt 4):325-332.

Mikosza AS, La T, Brooke CJ, Lindboe CF, Ward PB, Heine RG, et al. (1999). PCR amplification from fixed tissue indicates frequent involvement of Brachyspira aalborgi in human intestinal spirochetosis. J Clin Microbiol. 37(6):2093-2098.

Mikosza AS, La T, Margawani KR, Brooke CJ, Hampson DJ (2001). PCR detection of Brachyspira aalborgi and Brachyspira pilosicoli in human faeces. FEMS Microbiol Lett. 197(2):167-170.

Muniappa N, Mathiesen MR, Duhamel GE (1997). Laboratory identification and enteropathogenicity testing of Serpulina pilosicoli associated with porcine colonic spirochetosis. J Vet Diagn Invest. 9(2):165-171.

Munshi MA, Traub RJ, Robertson ID, Mikosza AS, Hampson DJ (2004). Colonization and risk factors for Brachyspira aalborgi and Brachyspira pilosicoli in humans and dogs on tea estates in Assam, India. Epidemiol Infect. 132(1):137-144.

Nathues H, Oliveira CJ, Wurm M, Grosse Beilage E, Givisiez PE (2007). Simultaneous detection of Brachyspira hyodysenteriae, Brachyspira pilosicoli and Lawsonia intracellularis in porcine faeces and tissue samples by multiplex-PCR. J Vet Med A Physiol Pathol Clin Med. 54(9):532538.

Oxberry SL, Hampson DJ (2003). Colonisation of pet shop puppies with Brachyspira pilosicoli. Vet Microbiol. 93(2):167-174.

Rasback T, Fellstrom C, Gunnarsson A, Aspan A (2006). Comparison of culture and biochemical tests with PCR for detection of Brachyspira hyodysenteriae and Brachyspira pilosicoli. J Microbiol Methods. 66(2):347-353.

Stanton TB, Fournie-Amazouz E, Postic D, Trott DJ, Grimont PA, Baranton G, et al. (1997). Recognition of two new species of intestinal spirochetes: Serpulina intermedia sp. nov. and Serpulina murdochii sp. nov. Int J Syst Bacteriol. 47(4):1007-1012.

Stege H, Jensen TK, Moller K, Baekbo P, Jorsal SE (2000). Prevalence of intestinal pathogens in Danish finishing pig herds. Prev Vet Med. 46(4):279-292.

Swayne D, McLaren A. Avian intestinal spirochaetes and avian intestinal spirochaetosis. In: TB HDaS, editor. Intestinal Spirochaetosis in Domestic Animals and Humans Wallingford, UK1997. p. 267-300.

Takeuchi A, Jervis HR, Nakazawa H, Robinson DM (1974). Spiral-shaped organisms on the surface colonic epithelium of the monkey and man. Am J Clin Nutr. 27(11):1287-1296. 
Trott DJ, Combs BG, Mikosza AS, Oxberry SL, Robertson ID, Passey M, et al. (1997). The prevalence of Serpulina pilosicoli in humans and domestic animals in the Eastern Highlands of Papua New Guinea. Epidemiol Infect. 119(3):369-379.

Trott DJ, Hampson DJ (1998). Evaluation of day-old specific pathogen-free chicks as an experimental model for pathogenicity testing of intestinal spirochaete species. Journal of Comparative Pathology. 118(4):365-381.

Trott DJ, Huxtable CR, Hampson DJ (1996). Experimental infection of newly weaned pigs with human and porcine strains of Serpulina pilosicoli. Infect Immun. 64(11):4648-4654. 